\title{
Effect of Insulin on Leucine Kinetics in Maple Syrup Urine Disease
}

\author{
J. E. COllins, A. M. UMPLEBY, M. A. BOROUJERDI, J. V. LEONARD, AND P. H. SONKSEN \\ Department of Child Health [J.E.C., J.V.L.], Institute of Child Health and Department of Medicine [A.M.U., \\ M.A.B., P.H.S.J, St. Thomas's Hospital Medical School, London, England
}

\begin{abstract}
Leucine turnover was measured using $\left[1-{ }^{14} \mathrm{C}\right]$ L-leucine in three patients with classical maple syrup urine disease. There was measurable leucine oxidation although it was lower than in normal adults. Leucine production rate was greater than normal in all three patients with an increased rate of incorporation of leucine into protein and increased protein catabolism. These fluxes were both relatively insensitive to exogenous insulin. (Pediatr Res 21: 10-13, 1987)
\end{abstract}

\section{Abbreviations}

MSUD, Maple syrup urine disease BCAA, branched-chain amino acids MCR, metabolic clearance rate

In MSUD the BCAA leucine, valine, and isoleucine, and their respective oxoacids are elevated as a result of deficient activity of the branched chain oxoacid dehydrogenase (E.C. 1.2.4.4) (1). Most patients with the severe (classical) form of the disease present in the neonatal period with overwhelming illness. Once the acute metabolic disorder has been controlled they are treated with a strict diet limiting the intake of the BCAA and yet providing sufficient of these and other essential amino acids for normal growth.

During intercurrent illness plasma concentrations of BCAAs and their oxoacids may rise rapidly owing to increased protein catabolism. The accumulation of metabolites may cause metabolic acidosis and potentially fatal encephalopathy. Insulin reduces leucine production rate (a measure of protein breakdown) in diabetic patients $(2,3)$ and an inverse relationship between plasma insulin and the BCAA concentration has been demonstrated (4). Insulin has also been shown to have important protein sparing effects in severely ill and traumatized patients, such as those with extensive burns, although the effective dose may need to be as much as $0.4 \mathrm{U.kg}{ }^{-1} \mathrm{~h}^{-1}$ because of relative insulin resistance $(5,6)$. Thus insulin may be useful in the management of patients with MSUD (7).

We report three patients with classical MSUD in whom we have measured leucine production and turnover before and during an insulin infusion.

\section{PATIENTS AND METHODS}

The project was approved by the Ethical Committee of the Joint Research Board of the Hospitals for Sick Children and the Institute of Child Health. The use of radioactive isotopes was

Received May 28, 1985; accepted August 6, 1986.

Correspondence: Dr. J. V. Leonard, Department of Child Health, Institute of Child Health, 30 Guilford Street, London WCI, U.K.

J.E.C. was supported by a training fellowship from the National Fund for Research into Crippling Diseases. approved by the Administration of Radioactive Substances Advisory Committee of the Department of Health and Social Security. The investigations were explained in detail to the patients and parents. Written consent was obtained in all cases.

Patients. Classical MSUD was diagnosed in the neonatal period in all three patients. All had grossly elevated plasma BCAAs at presentation (plasma leucine $>3000 \mu \mathrm{mol} . \mathrm{l}^{-1}$ ) and were treated with a diet restricting leucine intake to less than $4.6 \mathrm{mmol}^{-d a y^{-1}}$ $\left(603\right.$ mg. day $\left.^{-1}\right)(8)$.

Patients 1 and 2 were 12 yr of age at the time of the study with an IQ on the WISC-R scale of 69 and 63, respectively. Patient 3 was $23 \mathrm{yr}$ of age, living independently, and employed full-time. All three patients were of normal height and weight. Patient 1: weight, $47 \mathrm{~kg}(75 \%)$, height, $152 \mathrm{~cm}(75 \%)$; patient $2:$ weight, 45 $\mathrm{kg}(75 \%)$, height, $156 \mathrm{~cm}(10 \%)$; and patient 3: weight, $47 \mathrm{~kg}$ (3\%), height, $160 \mathrm{~cm}(25 \%)$.

The patients were studied $3 \mathrm{~h}$ after a light protein-free breakfast. Each received an infusion of $\left[1-{ }^{14} \mathrm{C}\right] \mathrm{L}$-leucine $(50-59$ mCi.mmol ${ }^{-1}$ ) (Amersham International). In patients 1 and 2 a total dose of $50 \mu \mathrm{Ci}$ was given over 150 min with insulin being infused at a rate of $0.05 \mathrm{U} . \mathrm{kg}^{-1} \mathrm{~h}^{-1}$ between 90 and $150 \mathrm{~min}$. In patient 3 a total dose of $80 \mu \mathrm{Ci}$ was administered over $210 \mathrm{~min}$ with an insulin infusion of $0.1 \mathrm{U} . \mathrm{kg} \cdot{ }^{-1} \mathrm{~h}^{-1}$ from $150 \mathrm{~min}$. Plasma was collected for the measurement of leucine specific activity and other metabolites and expired air for the measurement of $\mathrm{CO}_{2}$ specific activity immediately before the study and every 15 min in patients 1 and 2 and every $20 \mathrm{~min}$ in patient 3 until the start of the insulin infusion when the time interval was decreased to $10 \mathrm{~min}$ in each patient. Urine was collected for the measurement of leucine excretion in patient 3.

In a separate experiment in patient 1 the effect of an insulin infusion of $0.3 \mathrm{U.kg} .^{-1} \mathrm{~h}^{-1}$ on plasma leucine was studied but no isotope was given and the patient's blood glucose was maintained in the normal range using a glucose clamp (9).

Normal adults. Ten normal adults (two female and eight male) with an age range of 18-52 yr (mean 36, SD $11 \mathrm{yr}$ ) and a weight range of $55-92 \mathrm{~kg}$ (mean 73, SD $11 \mathrm{~kg}$ ) were studied the morning after an overnight fast using a $25 \mu \mathrm{Ci}$ bolus of $\left[1-{ }^{14} \mathrm{C}\right] \mathrm{L}-$-leucine. Plasma was collected immediately before the injection for baseline measurements and then every minute to $5 \mathrm{~min}$, at 8 and 10 $\mathrm{min}$, and then every $10 \mathrm{~min}$ to $120 \mathrm{~min}$. Expired air was collected every 4 to $20 \mathrm{~min}$ and then every $20 \mathrm{~min}$ until the end of the study.

Methods. Plasma leucine was measured by split stream analysis on a Chromaspek (Hilger Analytical) amino acid analyzer. ${ }^{14} \mathrm{CO}_{2}$ was measured using the method of Kaihara and Wagner (10). The total volume of distribution of leucine was calculated from the metabolic clearance rate and mean residence time. Measurements of leucine metabolism were calculated using a six compartment model of leucine and bicarbonate kinetics (Fig. 1), the number of compartments being determined from the number of exponentials fitting the curve (3). The leucine subsystem is represented by compartments $1-3$ and the bicarbonate subsystem 
by compartments $4-6$. Compartment 1 was fixed as plasma volume and compartment 2 as the site for leucine oxidation (represented by the rate constant $\mathrm{K}_{42}$ in Fig. 1) and protein synthesis $\left(\mathrm{K}_{\mathrm{P}_{2}}\right)$. Compartment 2 therefore contains both extracellular and intracellular components. Compartment 3 may represent a site of proteolysis but not protein synthesis which has been described in several models of amino acid metabolism in isolated tissues (11). The site of net inflow of unlabelled leucine is unknown. The bicarbonate subsystem is based on the model of Steele (12) and adapted by Waterhouse et al. (13) in which the central compartment is the blood pool. This model which is both mathematically identifiable and physiologically sound was previously established in normal subjects $(3,14)$. The parameters of the leucine subsystem and the bicarbonate subsystem were estimated by a process of adaptive fitting for the minimum sum of squares error (15) to the plasma leucine specific activity curve and the $\mathrm{CO}_{2}$ specific activity curve, respectively. In the studies in which a steady state level of leucine activity was not achieved before insulin administration (patients 1 and 2) the steady state level of leucine activity was predicted using the parameter estimates of the leucine subsystem. Leucine MCR, production rate, percent leucine oxidation and the rate of leucine incorporation into protein were calculated from the following equations:

Leucine $\mathrm{MCR}=\frac{\text { infusion rate }\left(\mathrm{dpm} \cdot \mathrm{min}^{-1}\right)}{\text { leucine at steady state }\left(\mathrm{dpm} \cdot \mathrm{ml}^{-1}\right)}$

$$
\times \frac{1}{\text { body wt }(\mathrm{kg})}
$$

Leucine production rate $\left(\mu \mathrm{mol} . \mathrm{min} .^{-1} \mathrm{~kg}^{-1}\right)$

$$
\begin{aligned}
& =\text { leucine } \mathrm{MCR}\left(\mathrm{ml} . \mathrm{min} .^{-1} \mathrm{~kg}^{-1}\right) \\
& \quad \times \text { leucine concentration }\left(\mu \mathrm{mol}^{\left.-\mathrm{l}^{-1}\right)}\right.
\end{aligned}
$$$$
\% \text { Leucine oxidation rate }=\frac{\mathrm{K}_{42}}{\mathrm{~K}_{\mathrm{P} 2}+\mathrm{K}_{42}} \times 100
$$

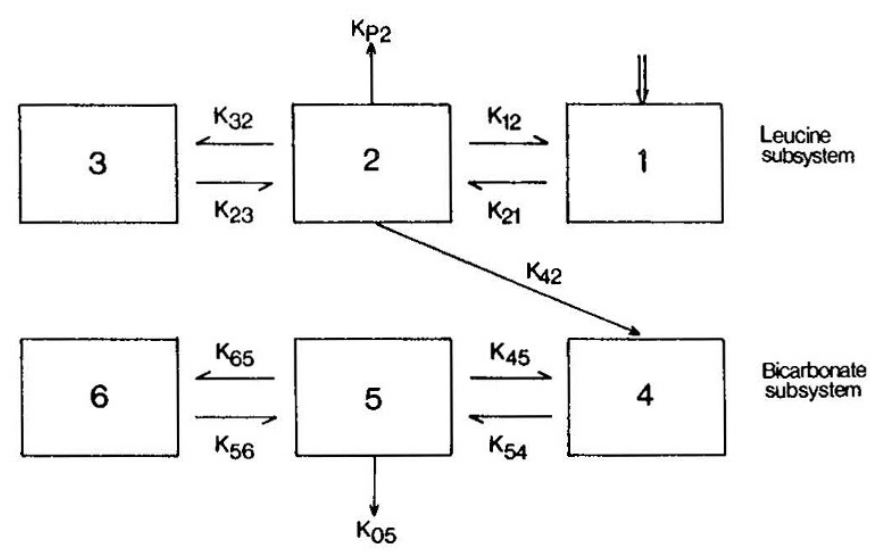

Fig. 1. Compartmental model of leucine and bicarbonate kinetics (10). The leucine subsystem is represented by compartments $1-3$ and the bicarbonate subsystem by compartments $4-6 . K_{\mathrm{P} 2}$ is the rate constant for protein synthesis and $\mathrm{K}_{42}$ the rate constant for leucine oxidation.
Rate of leucine incorporation into protein $\left(\mu \mathrm{mol} . \mathrm{min} .^{-1} \mathrm{~kg}^{-1}\right)$

$$
\begin{aligned}
& =\text { leucine production rate }\left(\mu \text { mol.min. } .^{-1} \mathrm{~kg}^{-1}\right) \\
& - \text { leucine oxidation rate }\left(\mu \text { mol.min. } .^{-1} \mathrm{~kg}^{-1}\right)
\end{aligned}
$$

Leucine oxidation rate was calculated assuming any recycling of ${ }^{14} \mathrm{CO}_{2}$ into other metabolites was negligible. Recovery of ${ }^{14} \mathrm{CO}_{2}$ has been found to be $95 \%$ following administration of $\mathrm{NaH}^{14} \mathrm{CO}_{3}$ in man (Umpleby AM, Boroujerdi MA, Sonksen PH, unpublished observations).

Following insulin administration there was no change in leucine specific activity (dpm. $\left.\mathrm{ml}^{-1}\right)$ implying no change in leucine MCR. Plasma leucine concentration $\left(\mu \mathrm{mol} . \mathrm{ml}^{-1}\right)$ was then simulated by reducing the leucine production rate (with a step change and a time constant of $20 \mathrm{~min}$ ) until an optimal fit to the concentration curve was obtained. Leucine disappearance rate was calculated from the product of the MCR and the simulated plasma leucine concentration curve (3). Intermediary metabolites and insulin were measured using standard methods.

\section{RESULTS}

Before the insulin infusion. All three patients had elevated plasma leucine concentrations before the start of the study but the total volume of distribution of leucine was normal (Table 1). The percentage of leucine oxidized and the MCR were lower and the leucine production rate greater than in normal adults (Table 1). Thus the rate of leucine incorporation into protein was greater than in the normal subjects. The rate of leucine excretion was not measured in patients 1 and 2 because they were unable to pass urine but in patient 3 the rate of leucine excretion was negligible at $0.0095 \mu$ mol.min. ${ }^{-1} \mathrm{~kg}^{-1}$ [normal adults: mean 0.00046 , SD $0.0002 \mu \mathrm{mol} . \mathrm{min} .^{-1} \mathrm{~kg}^{-1}$ (16)]. Plasma glucose, lactate, free fatty acids and ketone bodies were all normal (Table 2).

Effect of the insulin infusion. An insulin infusion of 0.05 U.kg. ${ }^{-1} h^{-1}$ in patients 1 and 2 produced no significant change in plasma leucine or leucine oxidation, metabolic clearance rate, production rate, or leucine incorporation into protein (Fig. 2). When 0.3 U.kg. ${ }^{-1} \mathrm{~h}^{-1}$ of insulin was infused in patient 1 plasma leucine fell from a mean of 324 to $276 \mu$ mol. $1^{-1}$ in 30 min. In patient 3 when 0.1 U.kg. ${ }^{-1} \mathrm{~h}^{-1}$ of insulin was infused plasma leucine fell from a mean of 755 to $587 \mu \mathrm{mol}^{-1}$ and the leucine production rate decreased from 2.51 to $1.96 \mu$ mol.min. ${ }^{-1} \mathrm{~kg}^{-1}$ after $1 \mathrm{~h}$ (Figs. 2 and 3). There was no effect on leucine MCR (3.34 ml.min. ${ }^{-1} \mathrm{~kg}^{-1}$ ).

Plasma glucose fell by less than $1.5 \mathrm{mmol} . \mathrm{1}^{-1}$ in patients 1 and

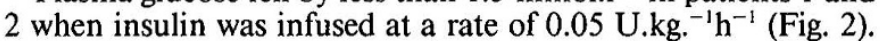
Patient 3 developed symptomatic hypoglycemia $50 \mathrm{~min}$ after the start of the insulin infusion (blood glucose $2.0 \mathrm{mmol}^{-1} \mathrm{l}^{-1}$ ) and required a glucose infusion (Fig. 2). In all patients there was a slight fall in 3-hydroxybutyrate and acetoacetate, a marked fall

\begin{tabular}{|c|c|c|c|c|c|c|}
\hline Patient & $\begin{array}{c}\text { Mean plasma } \\
\text { leucine } \\
\left(\mu \mathrm{mol} \cdot 1^{-1}\right)\end{array}$ & $\begin{array}{c}\text { Total volume of } \\
\text { distribution of } \\
\text { leucine } \\
\left(\mathrm{ml} \cdot \mathrm{kg}^{-1}\right)\end{array}$ & $\begin{array}{c}\text { Leucine } \\
\text { oxidation }(\%)\end{array}$ & $\begin{array}{c}\text { Leucine } \\
\text { production rate } \\
\left(\mu \mathrm{mol} \cdot \mathrm{min}^{-1} \text {. }\right. \\
\left.\mathrm{kg}^{-1}\right)\end{array}$ & $\begin{array}{c}\mathrm{MCR} \\
\left(\mathrm{ml} \cdot \mathrm{min}^{-1} \cdot \mathrm{kg}^{-1}\right)\end{array}$ & $\begin{array}{c}\text { Leucine } \\
\text { incorporation into } \\
\text { protein } \\
\left(\mu \mathrm{mol} \cdot \mathrm{min}^{-1} \cdot \mathrm{kg}^{-1}\right)\end{array}$ \\
\hline 1 & 485 & 445 & 2.53 & 2.45 & 5.05 & 2.39 \\
\hline 2 & 898 & 375 & 2.38 & 4.98 & 5.55 & 4.86 \\
\hline 3 & 755 & 450 & 4.53 & 2.51 & 3.32 & 4.00 \\
\hline $\begin{array}{l}\text { Normal adults } \\
\quad(\text { mean } \pm \mathrm{SD})\end{array}$ & $127 \pm 18$ & $466 \pm 154$ & $10.63 \pm 2.38$ & $1.78 \pm 0.43$ & $14.04 \pm 4.29$ & $1.59 \pm 0.38$ \\
\hline (Range) & $(91-163)$ & $(312-620)$ & $(5.87-15.39)$ & $(0.92-2.64)$ & $(5.46-22.62)$ & $(0.83-2.35)$ \\
\hline
\end{tabular}
in free fatty acids, and a slight rise in lactate during the insulin infusion; the changes were similar at both infusion rates (Table 2).

Table 1. Leucine kinetics before the insulin infusion 
Table 2. Intermediary metabolites before and after the insulin infusion

\begin{tabular}{|c|c|c|c|c|c|c|c|c|}
\hline \multirow[b]{2}{*}{ Patient } & \multicolumn{2}{|c|}{ Lactate $\left(\mathrm{mmol} \cdot \mathrm{l}^{-1}\right)$} & \multicolumn{2}{|c|}{$\begin{array}{l}3 \text { Hydroxybutyrate } \\
\left(\mathrm{mmol} \cdot \mathrm{l}^{-1}\right)\end{array}$} & \multicolumn{2}{|c|}{$\begin{array}{l}\text { Acetoacetate } \\
\left(\mathrm{mmol} \cdot \mathrm{l}^{-1}\right)\end{array}$} & \multicolumn{2}{|c|}{$\begin{array}{l}\text { Free fatty acids } \\
\qquad\left(\mathrm{mmol} \cdot \mathrm{l}^{-1}\right)\end{array}$} \\
\hline & Before & After & Before & After & Before & After & Before & After \\
\hline 2 & 0.73 & 0.78 & 0.08 & 0.03 & 0.04 & 0.03 & 0.58 & 0.20 \\
\hline 3 & 0.43 & 0.62 & 0.10 & 0.02 & 0.05 & 0.03 & 0.52 & 0.23 \\
\hline $\begin{array}{l}\text { Normal adults (mean } \\
\quad \pm \mathrm{SD} \text { ) }\end{array}$ & $0.52 \pm 0.37$ & & $0.05 \pm 0.02$ & & $0.05 \pm 0.02$ & & $0.51 \pm 0.14$ & \\
\hline
\end{tabular}

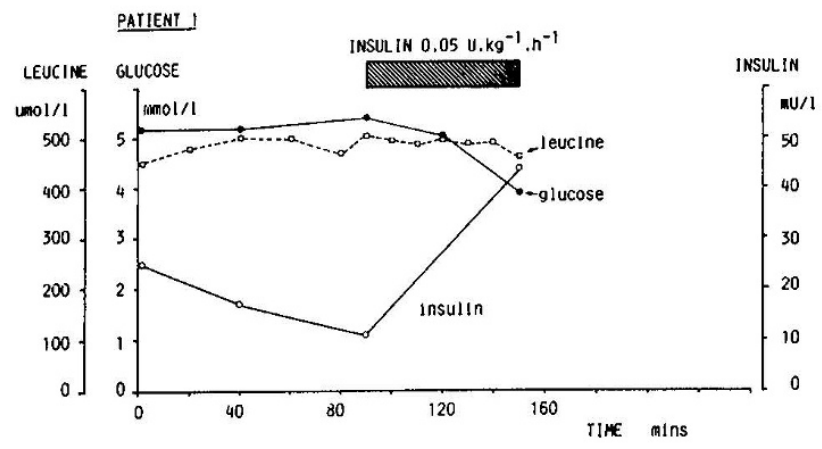

PATIENT 2
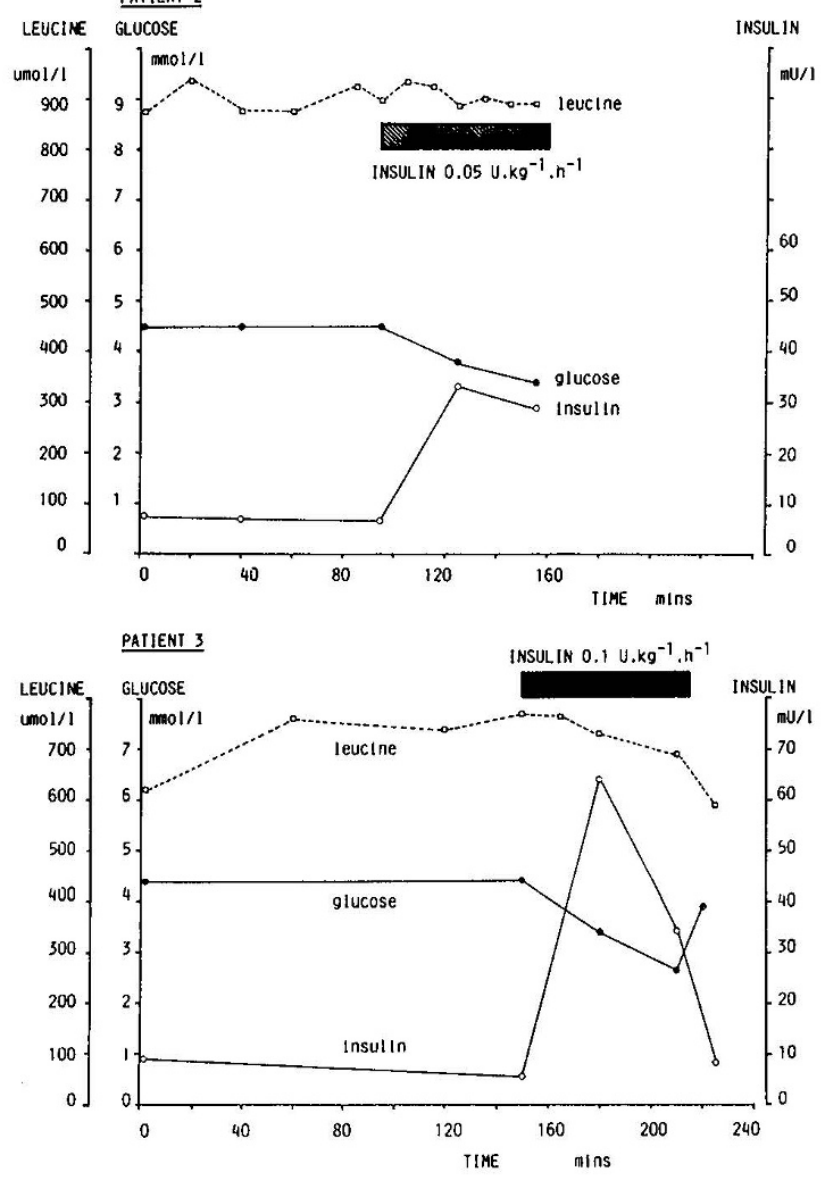

Fig. 2. The effect of an insulin infusion on plasma glucose, leucine, and insulin concentrations in the patients.

\section{DISCUSSION}

In MSUD elevated concentration of BCAAs have been assumed to be due to reduced activity of the branched-chain oxoacid dehydrogenase complex (1) since the oxidation of ${ }^{14} \mathrm{C}$ labelled BCAA in intact fibroblasts from patients with classical MSUD is less than $2 \%(17)$. However, in this study the percentage

\section{LEUCINE KINETICS}
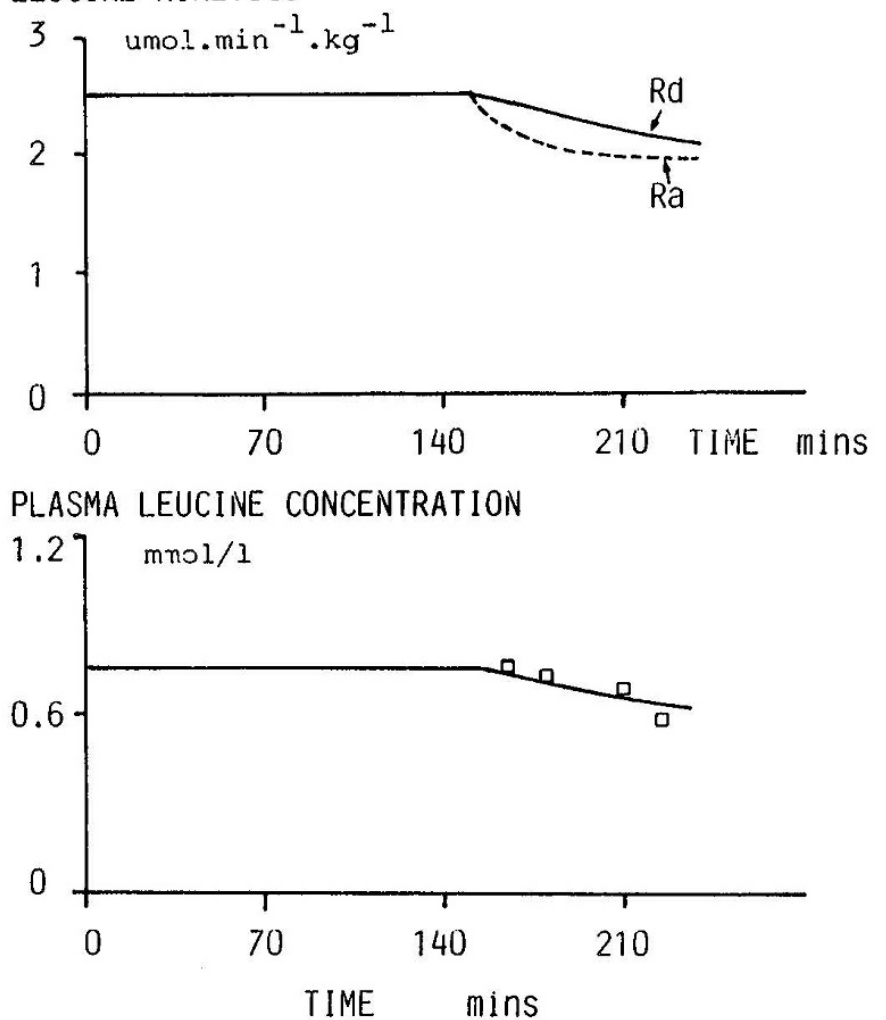

Fig. 3. Plasma leucine and model-predicted leucine production rate $(R a)$ and disappearance rate $(R d)$ in patient 3 before and during an insulin infusion of $0.1 \mathrm{U} . \mathrm{kg}^{-1} \mathrm{~h}^{-1}$.

oxidation in the three patients was not negligible, being between 22 and $43 \%$ of the normal mean. This unexpectedly high rate of leucine oxidation may have occurred for two reasons. At high plasma leucine concentrations there may be nonspecific oxidation by other enzymes or alternatively there may be residual enzyme activity.

The reduction in leucine MCR was partly due to decreased leucine oxidation but may also be due to saturation of the cellular transport mechanisms at the high plasma leucine concentrations found in these patients (18). However, decreased leucine MCR was not the major cause of the raised plasma leucine. In this study the high leucine concentrations were mainly due to increased leucine production rate.

Patient 3 was in a steady state before the insulin infusion was started and the kinetic parameters can be analyzed without the need to consider the nature and volumes of distribution of leucine. From the leucine specific activity at plateau $(1.71 \pm 0.03$ dpm.mmol ${ }^{-1}$, mean $\left.\pm \mathrm{SD}\right)$ and ${ }^{14} \mathrm{CO}_{2}$ production $(11007 \pm 346$ dpm. $\min ^{-1} \mathrm{~kg}^{-1}$ ) leucine oxidation $(4.53 \%)$, leucine production rate $\left(3.02 \mu \mathrm{mol} . \mathrm{min} .^{-1} \mathrm{~kg}^{-1}\right)$, and MCR $\left(4.0 \mathrm{ml} . \mathrm{min} .^{-1} \mathrm{~kg}^{-1}\right)$ were calculated. However patients 1 and 2 did not reach a steady state before the insulin infusion and therefore the data from all three patients was analyzed using a six compartment model. This has 
been validated in normal subjects and patients with diabetes mellitus, with and without an insulin infusion (3). Although patients with MSUD have elevated BCAA concentration their total volume of distribution of leucine was within the normal range and the results for patient 3 are in close agreement whether model derived or not. Therefore it appears valid to use the model in patients with MSUD.

The rate of leucine incorporation into protein was increased in these patients. This was calculated without subtraction of urinary losses of leucine. It was assumed that urine losses of leucine were negligible in all three patients since leucine excretion measured in patient 3 was low. The excretion of 2 oxoisocaproic acid (the oxoacid of leucine) was also assumed to be negligible. Since renal clearance of 2 oxoisocaproic acid has been reported to be between 0 and $0.355 \mathrm{ml} \cdot \mathrm{min}^{-1}$ (depending on the plasma leucine concentration) (19), patient 2 (with the highest plasma leucine concentration of $898 \mu \mathrm{mol}^{-1} \mathrm{l}^{-1}$ ) would have a maximum calculated excretion rate of only $0.007 \mu$ mol.min. ${ }^{-1} \mathrm{~kg}^{-1}$. Furthermore only $1 \%$ of the total dpm infused into patient 3 was recovered in the urine confirming that excretion of leucine and 2 oxoisocaproic acid were low and would have a negligible effect on leucine kinetics. Thus we conclude that both the rate of incorporation of leucine into protein, a measure of protein synthesis, and protein breakdown (as measured by leucine production rate) were increased.

Leucine has been demonstrated to stimulate protein synthesis in isolated rat skeletal muscle and perfused rat heart $(20,21)$. In MSUD the increased protein synthetic rate may be the result of the elevated plasma leucine concentrations with an increase in protein degradation maintaining protein balance. It should also be considered that patients 1 and 2 were $12 \mathrm{yr}$ of age and still growing so they might be expected to have a higher rate of protein turnover than normal adults. Patient 3, however, was 23 yr of age and had a higher rate of protein turnover than patient 1 , so it is more likely that the elevated protein turnover in all three patients was the result of their disease.

The insulin infusion had relatively little effect on protein turnover in these patients. This contrasts with studies in normal subjects in which an insulin infusion producing insulin concentrations similar to those achieved in patients 1 and 2 (i.e. an insulin infusion of $0.05 \mathrm{U.kg} \cdot{ }^{-1} \mathrm{~h}^{-1}$ ) has been shown to reduce leucine concentrations from 130 to $89 \mu \mathrm{mol} . \mathrm{I}^{-1}$ (22). In insulin withdrawn diabetics an insulin infusion of $0.04 \mathrm{U} \cdot \mathrm{kg}^{-1} \cdot \mathrm{h}^{-1}$ for 1 $\mathrm{h}$ has also been shown to reduce the leucine concentration from 240 to $180 \mu \mathrm{mol}^{-1}$. This suggests that in these MSUD patients the rate of protein turnover was insensitive to insulin. The response of plasma glucose to insulin, however, was normal in patient 3 and at the lower end of the normal range in patients 1 and 2 (24). Basal insulin levels were not increased and there was a normal response of free fatty acids and ketone body concentrations to the insulin infusions in all three patients. Strictly the patients cannot therefore be considered to be insulin resistant. These results suggest that for insulin to be effective in lowering leucine concentrations during the treatment of acute illness in MSUD the dose of insulin will have to be greater than that used in diabetics. A simultaneous glucose infusion will be necessary to prevent hypoglycemia.

We have shown that in patients with MSUD not only is there considerable oxidation of leucine but that there is an increase in leucine production rate and an increase in leucine incorporation into protein. These rates appear to be relatively insensitive to insulin.
Acknowledgments. The authors thank Dr. D. Brenton for allowing us to study patient 3, Dr. I. Scobie, and Dr. E. Naughten for assistance with the studies; Dr. E. R. Carson for helpful discussion about the leucine model; and Dr. P. Daish for constructive criticism of the manuscript.

\section{REFERENCES}

1. Tanaka K, Rosenberg LE 1984 Disorders of branched chain amino acid and organic acid metabolism. In: Stanbury JB, Wyngaarden JB. Frederickson DS, Goldstein JL, Brown MS (eds) The Metabolic Basis of Inherited Disease McGraw-Hill Book Company, New York, pp 440-473

2. Saunders J, Boroujerdi MA, Brown PM, Carson ER, Hall SEH, Umpleby AM, Sonksen PH 1982 Isotope turnover studies in uncontrolled diabetes and the effects of insulin. In: Metabolic Acidosis, Ciba Symposium 87. Pitman, Bath, pp 273-293

3. Umpleby AM, Boroujerdi MA, Brown PM, Carson ER, Sonksen PH 1986 The effect of insulin on leucine metabolism in insulin-dependent diabetic patients. Diabetologia 29:131-141

4. Berger M, Zimmerman-Tleschow H, Berchtold P, Drost H, Muller WA, Gries FA, Zimmerman H 1978 Blood amino acid levels in patients with insulin excess (functioning insulinoma) and insulin deficiency (diabetic ketosis). Metabolism 27:793-799

5. Hinton P, Littlejohn S, Allison SP, Lloyd J 1971 Insulin and glucose to reduce the catabolic response to injury in burned patients. Lancet 1:767-769

6. Woolfson AMJ, Heatley RV, Allison SP 1979 Insulin to inhibit protein catabolism after injury. N Engl J Med 300:14-17

7. Wendel U, Lombeck I, Bremer HJ, Langenbeck U 1982 Maple syrup urine disease-therapeutic use of insulin in catabolic states. Eur J Paediatr 139:172-175

8. Clow CL, Reade TR, Scriver CR 1981 Outcome of early and long term management of classical maple syrup urine disease. Pediatrics 68:856-862

9. DeFronzo RA, Tobin JD, Andres R 1979 Glucose clamp technique: a method for quantifying insulin secretion and resistance. Am J Physiol 237:E214-223

10. Kaihara S, Wagner HN 1968 Measurement of intestinal fat absorption with ${ }^{14} \mathrm{C}$ tracers. J Lab Clin Med 71:400-411

11. Mortimore GE, Woodside KH, Henry JE 1972 Compartmentation of free valine and its relation to protein turnover in perfused rat liver. J Biol Chem 247:2776-2784

12. Steele $\mathrm{R} 1955$ The retention of metabolic radioactive carbonate. Biochem $\mathrm{J}$ $60: 447-453$

13. Waterhouse C, Baker N, Rostami H 1969 Effect of glucose ingestion on the metabolism of free fatty acids in human subjects. J Lipid Res 10:487-494

14. Umpleby AM, Boroujerdi MA, Brown PM, Carson ER, Sonksen PH 1981 A compartment model of leucine and bicarbonate metabolism in man. Clin Sci 61:45P

15. Gill PE, Murray W 1976 Minimisation subject to bound on the variables. National Physical Laboratory Report. Her Majesty's Stationary Office, London

16. Liappis $\mathrm{N} 1973$ Geschlechtsspezifische unterschiede der freien aminosauren in urin von erwachsenen. Z Clin Chem Klin Biochem 11:279--385

17. Dancis J, Jansen V. Hutzler J. Levitz M 1963 The metabolism of leucine in tissue culture of skin fibroblasts of Maple Syrup Urine Disease. Biochem Biophys Acta 77:523-524

18. Hagenfeldt L, Errikson S, Wahren J 1980 Influence of leucine on arterial concentrations and regional exchange of amino acids in healthy subjects. Clin Sci 59:173-181

19. Langenbeck U, Wendel U, Luthe H 1979 Renal clearance of branched chain 2 oxoacids in maple syrup urine disease. J Clin Chim Clin Biochem 17:176

20. Buse GM, Weigard DA 1977 Studies concerning the specificity of the effect of leucine on the turnover of proteins in muscle of control and diabetic rats Biochim Biophys Acta 475:81-89

21. Chua B, Siehl DL, Morgan HE 1979 The effect of leucine turnover and metabolites of branched chain amino acids on protein turnover in heart. $\mathrm{J}$ Biol Chem 254:8358-8362

22. Tessari P, Trevisan R, Kreutzenberg SV, Nosadini R, Duner E, Tiengo A 1984 Characterisation of the dose response curves for the effects of insulin on leucine and alpha ketoisocaproate in vivo. In: Garrow JS, Halliday D (eds) Substrate and Energy metabolism in man. John Libbey, London, p A23 (abstr)

23. Brown PM 1984 A study of glucose metabolism using tracer methodology during administration of insulin, $A_{1} B_{29}$ dodecoyl insulin, salbutamol and alcohol in man. MD thesis, University of London

24. West TET, Owens D, Sonksen PH, Srivastava MC, Tompkins CV, Nabarro JDN 1975 Metabolic responses to monocomponent human insulin infusions in normal subjects and patients with liver and endocrine disease. Clin Endocrinol 4:573-584 